\title{
iaspm@journal
}

ISSN 2079-3871

\section{ReVIEW | How To Write About Music... with advice from industry-leading writers}

Marc Woodworth and Ally-Jane Grossan, Eds. New York and London: Bloomsbury Academic, 2015

ISBN: 978-1-6289-2043-7 (PB)

\section{John Mullen}

\section{Université Paris Est Créteil \\ john.mullen@univ-rouen.fr}

Not a book you get bored with, though you might feel irritated almost as often as enlightened. This volume is made up of a large number of short writings on Western popular music (mostly canonical but sometimes underground) along with endless advice from writers on what to do if you want your writing for fans to be published and paid for. It has been put together by the editors of the $331 / 3$ series, an endeavour now counting a hundred books, each analysing one music album from recent decades.

The book has three different aspects. Firstly, it is indisputably itself a rock object. Filled with short and pithy productions with soundbites and neologisms galore ("Keep your overhead low and your expectations lower"; "He plays [drums] like D H Lawrence writes"; "Music writing is the crack cocaine of non-fiction writing"; "You could say Punk rock is anger's schmaltz"), it is often unbearably hip. Right from the foreword, packed with exclamation marks, you know what you are in for. It has all the rock attitudes: sentimentality ("our beloved 33 1/3 series", write "for love or not at all"); hyperbole (this series has "revolutionized contemporary rock criticism"); melodrama ("great albums still completely fuck my whole life up"; you should write about music "in exactly the same way that you would write a suicide note"); and contradiction (advice from "people who themselves avoided all the advice anyone 
ever gave them"). The music writers are interviewed as if they were themselves minor rock stars ("How did you land your job?" "How is music writing different?" "Where do you find inspiration?" "Who is your dream interview subject?" "Which three songs, two objects and one novel would you take on a desert island?") One writer "would so love to take Oscar Wilde out to karaoke", innit?

Secondly, this is a manual for would-be writers on rock and pop music, featuring a few hundred short paragraphs of advice from a few dozen authors ("expert advice from our writers"). Although the back cover exclaims that the tome is "crammed full of stellar advice", the tips given are of extremely uneven quality. Some are embarrassingly obvious (for an album review "begin by listening to the disc in question several times"; for the artist interview "don't read from your notes too much" and in general "Use Google to check your facts", and "don't trust Wikipedia as your sole source"). Some are just not interesting ("What was your biggest mistake?" "I totally trashed an album in my college newspaper that later became one of my favorites"; "How has the field of music-writing changed?" "It's better in some ways and worse in others - very difficult to say"). One section is actually labelled "offbeat advice" although its contents is sometimes less than wacky ("I always file on time"; "I try to have a clear picture in mind of who reads what I wrote"). In the last pages, one of the star writers seems to undermine the whole exercise: "I think that reading other music writing is often a trap".

As well as the tips from "industry-leading writers" ${ }^{1}$ the reader is provided with a series of "writing prompts" - practice exercises for budding writers (Write an album review about a group you know nothing about; go to a concert and write about it to deadline, write a 2000-word essay that explores your connection to a single song). Useful for college courses on music writing (I'm assuming such courses exist). Clearly, the editors felt there were a lot of people who would buy a book aimed at helping them to get published. Some of the advice may serve its purpose, this is difficult to judge.

Finally and mostly, the volume is an anthology of forty-eight pieces of writing on a vast variety of Western popular music of recent decades (with one or two older themes). Different kinds of articles each get a chapter: album reviews, concert reviews, artist interviews, personal essays, artist profiles, scene analyses, musical analyses, "cultural criticism", and experimental writing (including novelettes based on music albums, and an extract from a graphic novel about Black Flag).

As a whistle-stop tour around today's journalistic writing on popular music, the book stands up very well. You can read chirpy concert reviews written as if we were all young ("She's like Chris Ware, except not, except totally"). The style is sometimes enjoyably creative ("So much sass! Pickup trucks! Dads who are gonna beat up exboyfriends! I'LL TAKE IT"). True, there is also analysis you might find more pompous than illuminating ("Sociology [...] is an obvious functional drag, particularly when it subverts the move qua move by means of opaque non-magical causality"). But much of the writing is good. There is an insightful piece on Enya, and a thoughtful piece on computers and music. The best contributions are those which deal with how the creation of a sense of mythology through music works in Led Zeppelin's "Stairway to 
Heaven", with the emotional power of drumming and in particular that of The Who's drummer, Keith Moon, with the "mumfordization of pop", with Radiohead's image and music and with dance clubs in Kosovo. An article on how The Beatles chose instruments for "Strawberry Fields Forever" gives a fascinating glimpse of the different factors involved. The application of music theory to Kate Perry's "Teenage Dream" is very convincing. And one of my favourite pieces speaks against the rock consensus, in defence of sentimental music.

Several articles go into on what particular albums meant to particular young people (the writers) at a particular time. This category varies from the touching to the pretentious. But all in all, there is much which is worth reading if, as I have said, accompanied by an editorial tone which is dreadfully hip and with practically no analysis of what hip is and why it is. One occasionally gets an image of the music writer as someone who wants to be ever so rock'n'roll, yet still be at home for the kids every evening, rather than in a rickety old tour bus hundreds of miles away.

The book gives opinion and analysis from 41 men and 4 women (and the 4 women write less than the average male contributor). A less generous or more feminist reviewer than myself might be tempted to suggest the book be re-titled "How men have written about popular music". This points up a major flaw, since in all the plethoric advice about how to write about music, the question of what to do if you're a woman writer is not mentioned. This is all the more surprising as one of the editors has previously written a book on women singer-songwriters (Woodford 1998), so must presumably have a feel for gender issues in the business.

There is plenty to please and educate in here. Many people who read this review are used to writing about music in a less hip manner, since there are in reality many ways of carrying out such a task, but it does us no harm to see how the other half lives.

\section{Endnotes}

${ }^{1}$ For an analysis of the industrialization of popular music criticism, and a general view of changes in content due to this industrialization, see Connor and Jones (2014).

\section{References}

Connor, T., and Jones, S. 2014. Art to Commerce: The Trajectory of Popular Music Criticism. IASPM@journal 4 (2): 7-23. http://dx.doi.org/10.5429/20793871(2014)v4i2.2en.

Woodford, M. 1998. Solo: Women Singer-Songwriters. New York, Dell. 